\title{
Detection of water vapor time variations associated with heavy rain in northern Italy by geodetic and low-cost GNSS receivers
}

\author{
Stefano Barindelli ${ }^{1}$, Eugenio Realini ${ }^{2 *} \mathbb{0}$, Giovanna Venuti $^{1}$, Alessandro Fermi ${ }^{1}$ and Andrea Gatti ${ }^{1}$
}

\begin{abstract}
GNSS atmospheric water vapor monitoring is not yet routinely performed in Italy, particularly at the regional scale. However, in order to support the activities of regional environmental protection agencies, there is a widespread need to improve forecasting of heavy rainfall events. Localized convective rain forecasts are often misplaced in space and/ or time, causing inefficiencies in risk mitigation activities. Water vapor information can be used to improve these forecasts. In collaboration with the environmental protection agencies of the Lombardy and Piedmont regions in northern Italy, we have collected and processed GNSS and weather station datasets for two heavy rain events: one which was spatially widespread, and another which was limited to few square kilometers. The time variations in water vapor derived from a regional GNSS network with inter-station distances on the order of $50 \mathrm{~km}$ were analyzed, and the relationship between the time variations and the evolution of the rain events was evaluated. Results showed a signature associated with the passage of the widespread rain front over each GNSS station within the area of interest. There was a peak in the precipitable water vapor value when the heavier precipitation area surrounded the station, followed by a steep decrease (5-10 $\mathrm{mm}$ in about $1 \mathrm{~h}$ ) as the rainclouds moved past the station. The smaller-scale event, a convective storm a few kilometers in extent, was not detected by the regional GNSS network, but strong fluctuations in water vapor were detected by a low-cost station located near the area of interest.
\end{abstract}

Keywords: GNSS meteorology, PWV variations, Intense rainfall

\section{Introduction}

Global navigation satellite systems (GNSS) meteorology (Bevis et al. 1992) relies on estimating the GNSS signal propagation delays induced by the presence of water vapor in the lower troposphere. GNSS-based tropospheric water vapor monitoring is used for operational meteorology in only a few countries, e.g., Japan (JMA 2013), the UK, and France (Bennitt and Jupp 2012; Guerova et al. 2016). In these countries, time series of zenith total delays (ZTD) or precipitable water vapor (PWV), derived from GNSS observations which are continuously collected by permanent regional networks of geodetic receivers, are routinely assimilated into mesoscale

\footnotetext{
*Correspondence: eugenio.realini@g-red.eu

${ }^{2}$ Geomatics Research and Development (GReD) srl, via Cavour 2, 22074 Lomazzo, Como, Italy

Full list of author information is available at the end of the article
}

numerical weather prediction (NWP) models (Bennitt and Jupp 2012; De Haan 2013; Saito et al. 2017). The use of GNSS for locally intense rainfall prediction is a current topic of research. In particular, the ability of hyper-dense GNSS networks (with receivers only a few kilometers apart) to provide observations at the necessary high spatial resolution is under investigation (Shoji et al. 2004; Deng et al. 2009; Sato et al. 2013). The hyper-dense networks can be supplemented by integrating GNSS-derived information with atmospheric artifacts retrieved from synthetic aperture radar (SAR) images (Onn 2006). Thus far, this solution has been realized only at an experimental level, but hyper-dense networks, possibly complemented by SAR-derived water vapor maps, are expected to soon be widespread at an operational level thanks to the augmented potentialities of GNSS system, the growing number of permanent stations, and the availability of increasingly high-performing low-cost receivers. Some 
of the authors of this paper are involved in this research and are working both on the deployment of dense networks of single-frequency receivers, which are already available on the market (within the $\mathrm{H} 2020$ project BRIGAID-http://brigaid.eu/), and on the development of low-cost dual-frequency sensors (EUROSTARS project EDWIGE-https://www.eurostars-eureka.eu/project/ id/10235).

Although Italy is endowed with numerous permanent GNSS stations for geodetic and surveying purposes, GNSS meteorology has not yet seen use in routine weather prediction and is still solely the domain of research. That research has taken several forms. Longterm ZTD time series derived from the European permanent network (EPN) have been analyzed (Pacione et al. 2013), and experimental studies on the use of GNSS data for the tomographic reconstruction of the refractivity field have been conducted (Notarpietro et al. 2011). GNSS-derived water vapor has been compared to other water vapor products (Basili et al. 2001; Boccolari et al. 2002; Ciotti et al. 2003; Cheng et al. 2012; Bonafoni and Biondi 2016). Finally, within the last decade, a few studies on the use of GNSS products for both regional- and local-scale meteorological events have been carried out (Faccani et al. 2005; Tammaro et al. 2016; Ferrando 2017).

Within this framework, we report on an experimental activity in northern Italy aimed at promoting the use of GNSS meteorology on an operational level. GNSS ZTD estimates and weather data were used to derive time series of PWV during a period in which two local, intense rainfall events occurred. The goal was to detect PWV time variations and evaluate their relationship to those events. Furthermore, an innovative potential solution to the need for higher spatial resolution water vapor monitoring was investigated: using low-cost GNSS sensors to densify existing networks.

The Piedmont and Lombardy regions in northwestern Italy are endowed with a GNSS permanent network, which is managed by an inter-regional positioning service called SPIN. The service freely delivers GNSS raw dualfrequency data at a 30-s rate. Two networks of weather stations collecting surface temperature and pressure data are present in the same area and are managed by two different regional environmental protection agencies (ARPA Lombardia and ARPA Piemonte). The two weather networks are integrated neither with one another nor with the GNSS network. Moreover, no Italian GNSS service delivers tropospheric delay or water vapor products, either for research or for operational purposes.

The GNSS data collected from the SPIN network during the two rain events were used to estimate ZTD time series by means of a free and open source software for GNSS data processing. The estimates were validated against results from state-of-the-art GNSS software. By using the estimated ZTD and properly interpolated weather data, PWV time series were computed and validated against independent radiosonde-derived PWV values. A first analysis of their variations in connection with the rain events was then carried out. Finally, the performance of a low-cost single-frequency GNSS station was investigated by a preliminary comparison of its PWV values against those of a near dual-frequency geodetic station.

In the following sections, we start by introducing the experimental setup and the processing used to obtain ZTD and GNSS-derived PWV time series from the GNSS and meteorological data. The internal and external validation procedures follow, and the analysis of the PWV variations and final considerations conclude the paper.

\section{Experimental setup and data processing}

The SPIN GNSS network comprises 30 permanent stations with inter-station distances of about $50 \mathrm{~km}$, uniformly distributed in the territories of the Piedmont and Lombardy regions (Fig. 1). During the period of interest, we collected 30-s RINEX observation files from all SPIN stations. In addition, we collected the RINEX files from CATU station, which belongs to the nationwide network NetGeo (deployed and managed by Topcon). The CATU station data were used to gain further insight into the local variations in water vapor in an area that was affected by very localized and strong convective precipitation, but where no SPIN receivers are present (see next section). In the same area, a low-cost single-frequency station (marker name GRED), deployed and continuously operated by Geomatics Research \& Development srl, is present. The data collected from this station were processed as well. The estimated ZTD were compared to those obtained from the nearest CATU geodetic receiver to evaluate to what extent a low-cost GNSS receiver and antenna could be used to detect water vapor variations. All geodetic stations are equipped with either Leica or Topcon receivers and antennas. The low-cost GRED station uses a u-blox LEA-6T receiver with a Tallysman L1 antenna.

The atmospheric pressure and temperature measurements needed to convert the GNSS-estimated tropospheric delay into PWV were obtained from two regional networks of weather stations operated by ARPA Piemonte and ARPA Lombardia environmental protection agencies. Data provided by ARPA Lombardia have a temporal resolution of $10 \mathrm{~min}$, while those provided by ARPA Piemonte have a temporal resolution of $30 \mathrm{~min}$. A subset of 35 stations was selected (Fig. 2) according to a proximity criterion with respect to the 30 GNSS stations. Further 


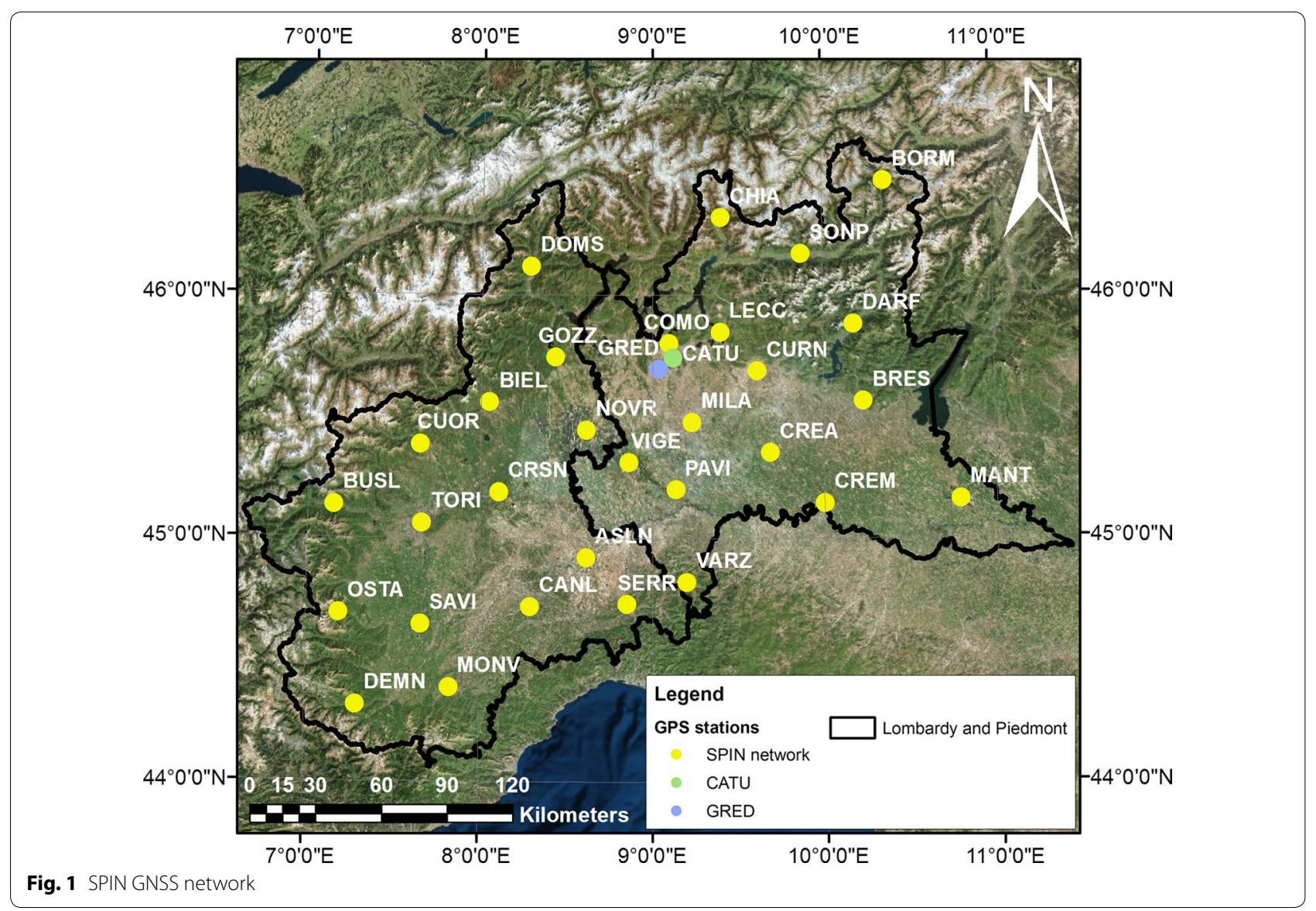

details about the GNSS and weather stations hardware setup are reported in "Appendix."

Figure 3 shows the position of the two radiosonde stations used for validation of GNSS-derived PWV. One is located in Lombardy [World Meteorological Organization (WMO) station identifier 16080, Milano Linate] and one in Piedmont (WMO station identifier 16113, Cuneo Levaldigi). Both stations launch one radiosonde every $12 \mathrm{~h}$.

The GNSS observation processing was carried out by means of the goGPS MATLAB open source software (Realini and Reguzzoni 2013; Herrera et al. 2016), modified by the authors to perform precise point positioning (PPP) (Kouba and Héroux 2001) and estimate ZTD values. The most recent version of the software, including the PPP module and ZTD estimation capability, is freely downloadable from the goGPS project GitHub page (https://github.com/goGPS-Project). Since the tropospheric delay estimation capability is a recent addition to the goGPS software, the final ZTD estimates were validated not only against radiosonde values, but also against an independent run of the state-of-the-art Bernese software (Dach et al. 2015), which uses its own
PPP algorithm. goGPS and Bernese apply their PPP algorithms in two different ways: Bernese implements a leastsquares post-processing adjustment of all observations collected during a given time period (in this case, daily) to jointly estimate coordinates and ZTD parameters, and goGPS adopts an extended Kalman filter. It should be noted that Caldera et al. (2016) already validated goGPS against Bernese with regard to precise relative positioning (Teunissen and Kleusberg 1998; Hoffman-Wellenhof et al. 2001) and demonstrated that the two software packages reach the same millimeter level of accuracy. goGPS and Bernese were run using the same processing parameters where possible: GPS-only observations, ionosphere-free combination of L1 and L2 observations, $10^{\circ}$ for the satellites elevation cutoff, global mapping function (Böhm et al. 2006), tropospheric gradient not estimated, I08.ATX PCO/PCV model, solid Earth tides model according to IERS convention, and ocean loading model FES2004. goGPS was set to a 30-s processing rate, while the Bernese processing rate was set to $10 \mathrm{~min}$, following the recommendations regarding its PPP implementation. Within goGPS, the coordinates dynamic model expresses the fact that the stations are fixed, and both the receiver 


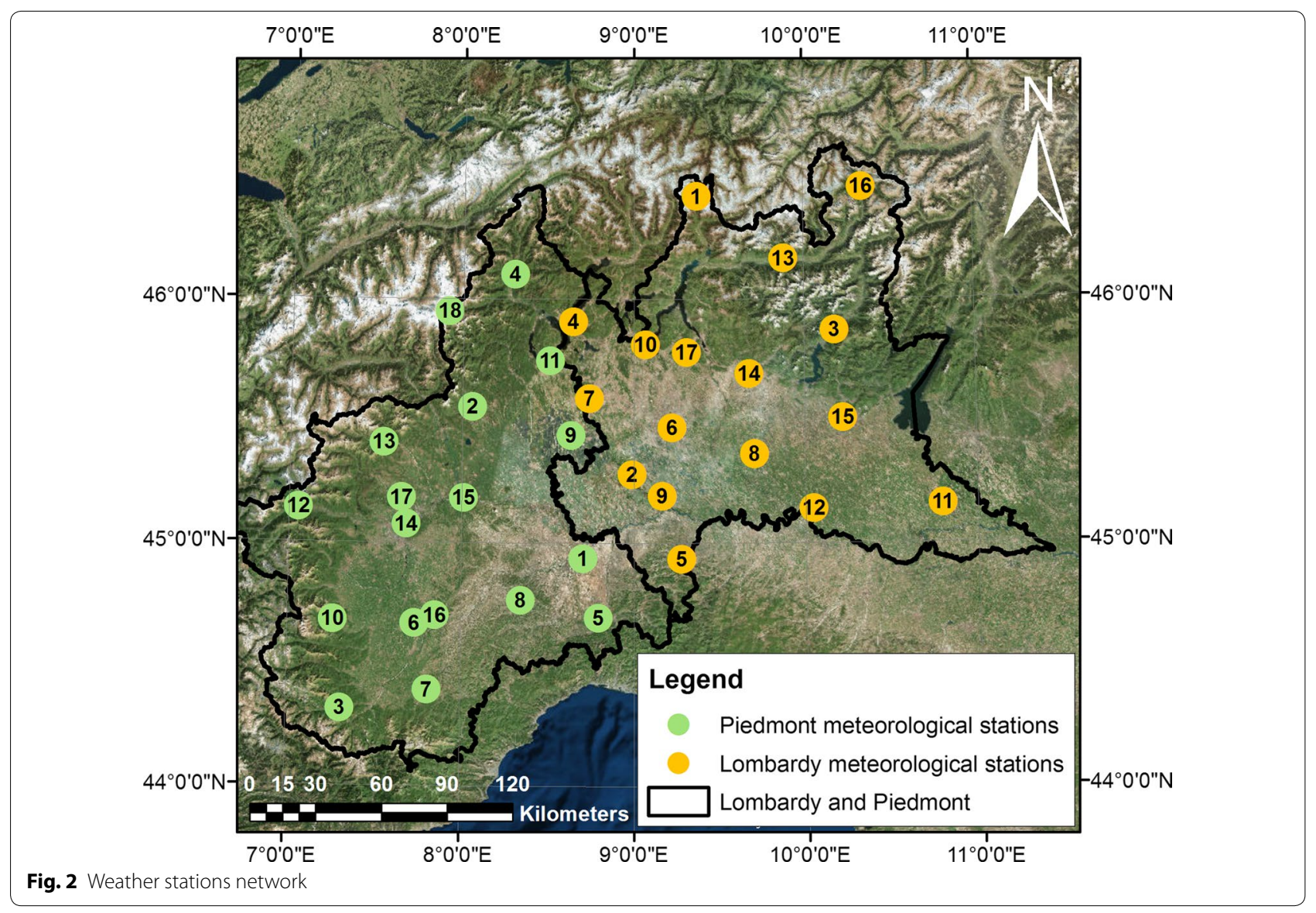

clock and ZTD parameters are modeled as random walk processes (Kouba and Héroux 2001). The sigma of the former is set to a large value to account for its unpredictable behavior, while that of the latter is modeled as:

$$
\sigma\left(\mathrm{ZTD}_{t+\Delta t}-\mathrm{ZTD}_{t}\right)=\sqrt{\Delta t} \cdot \sigma_{h}
$$

where $\sigma_{h}=1 \mathrm{~mm} / \sqrt{h}$. In the Bernese software, a new ZTD parameter is introduced every $10 \mathrm{~min}$ by linearly modeling its evolution within this interval. Therefore, each parameter accounts for the contribution of the tropospheric water vapor variations in the interval considered. Moreover, additional pseudo-observations are introduced, expressing a regularity of the ZTD behavior: the inclination of the linear function must be 0 with an a priori given standard deviation. In the present case, this standard deviation was set equal to $3 \mathrm{~mm}$. For the coordinates, a unique set of parameters is introduced for the whole daily time period under consideration.

Five of the 30 SPIN stations, namely ALSN, DEMN, GOZZ, SERR, and VIGE, were excluded due to high numbers of outliers and large gaps in code and phase observations. The remaining 25 GNSS stations were deemed sufficient both in number and in spatial distribution for the selected case studies.

Within the goGPS PPP algorithm, the ZTD update with respect to the value of the previous epoch depends on all the observations collected from the satellites which are simultaneously in view. The ZTD models the common projection of the delays affecting the considered GNSS signals along the zenith direction above the receiver and along their different receiver-satellite paths. The use of observations confined to a restricted volume around the zenith direction should in principle allow for a ZTD estimate closer to the actual zenith value. Such restriction, where possible, would weaken the acquisition system geometry, degrading all parameter estimates. However, all current GNSS software implements a weighted adjustment that makes the solution less dependent on the observations at low elevations above the horizon. In fact, although the weighted adjustment improves the estimates of the unknown parameters, such observations are noisier, mainly due to multipath effects (Dach et al. 2015). A weighted adjustment that expresses the observation accuracy as an increasing function of the elevation could be exploited to improve detection of the actual tropospheric 


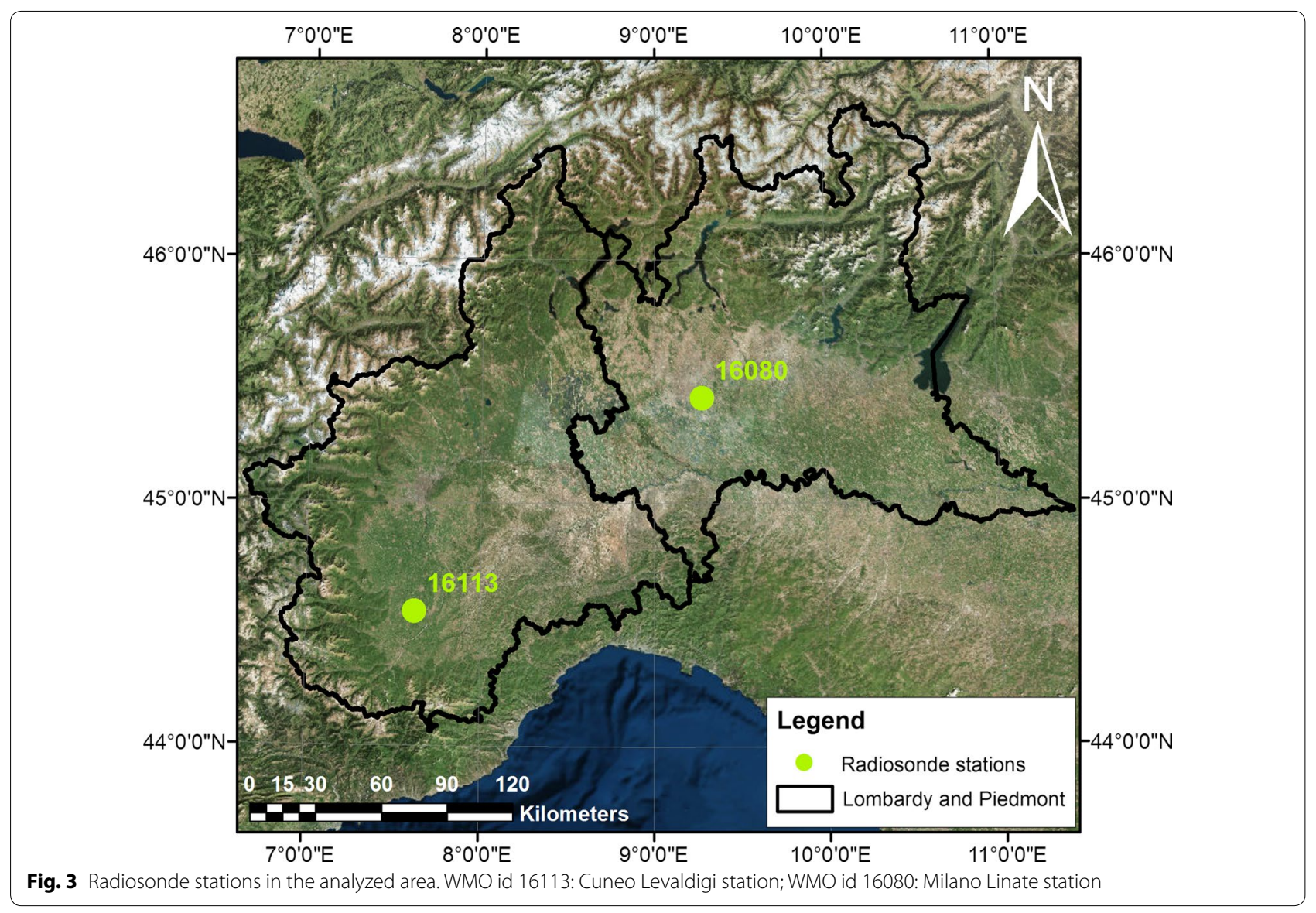

water vapor along the zenith direction above the receiver, which is our aim. A better solution, albeit one requiring a nonstandard analysis of the GNSS adjustment residuals, would be to reconstruct the satellite-receiver slant delays and, after selecting only those above a given elevation threshold, average their zenith projection [as in Sato et al. (2013)]. This approach presents some drawbacks: it requires the development of ad hoc software; the reconstructed slant delays could be affected by unmodeled multipath effects; and finally, the averaged zenith projection, which relies on a limited number of slant delays, is highly dependent on the sporadic contribution of a satellite which is in view for only a short period. In this paper we have thus decided to investigate the effect of observation weighting on goGPS-derived ZTD estimates. We expected the weighted solution to be more sensitive to the local state of the troposphere. Two different runs were performed: one without observation weighting and one with satellite elevation-dependent weighting based on the sine squared of the elevation angle.

To enable tropospheric delay estimation for the lowcost L1-only receiver, the ionospheric delay for the GRED station was interpolated from the three surrounding dual-frequency stations (namely COMO, NOVR, and MILA) by applying the Satellite-specific Epoch-differenced Ionospheric Delay (SEID) algorithm (Deng et al. 2009).

While data provided by GNSS stations have a common 30-s observation rate, the temperature and pressure data of the 35 available weather stations have different time resolutions (30 min for the Piemonte stations and $10 \mathrm{~min}$ for the Lombardia stations). These data were thus interpolated to match the GNSS observation rate and to fill some data gaps. This interpolation was done by means of a modified least-squares collocation (LSC) algorithm. The algorithm was applied to the time series of pressure and temperature of each meteorological station, which were modeled as random processes stationary within a time interval that depends on the gap size. The required covariance model was estimated from the data surrounding the prediction point.

The interpolated temperature and pressure time series of the weather stations were then associated with the GNSS stations according to the nearest neighbor criterion, and height corrections were applied following Realini et al. (2014). By exploiting the 30-s pressure time 

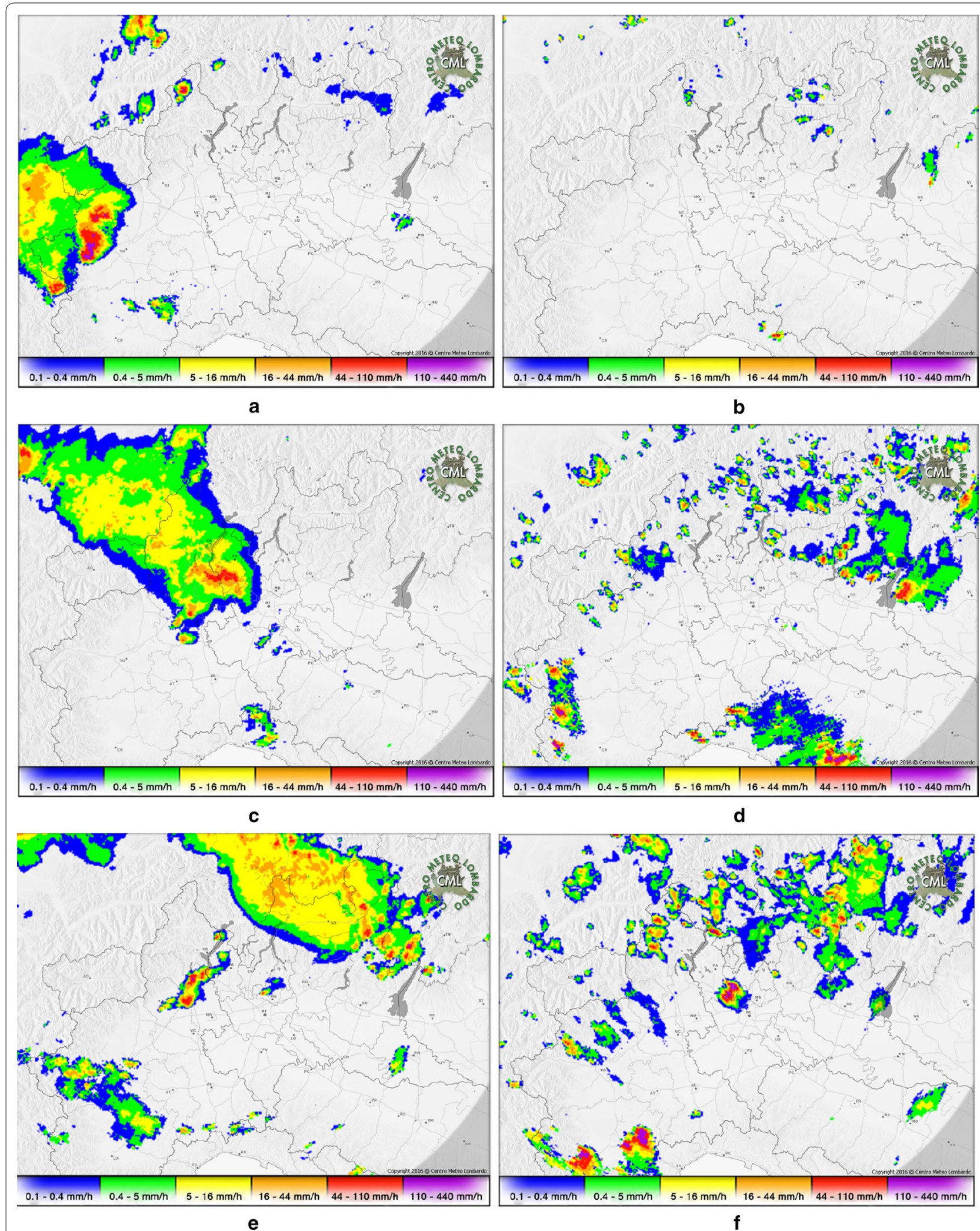

Fig. 4 Time progression of the July 22, 2016, event (a, $\mathbf{c}$, e) and the July 26, 2016, event $(\mathbf{b}, \mathbf{d}$, $\mathbf{f})$, as seen through precipitation intensity maps derived from radar reflectivity observations. Such maps are published by the Centro Meteo Lombardo-CML, based on MeteoSwiss radar data. LT local time. a July 22—07:00 LT. b July 26—12:00 LT. c July 22—10:00 LT. d July 26—15:00 LT. e July 22—13:00 LT. f July 26—18:00 LT 

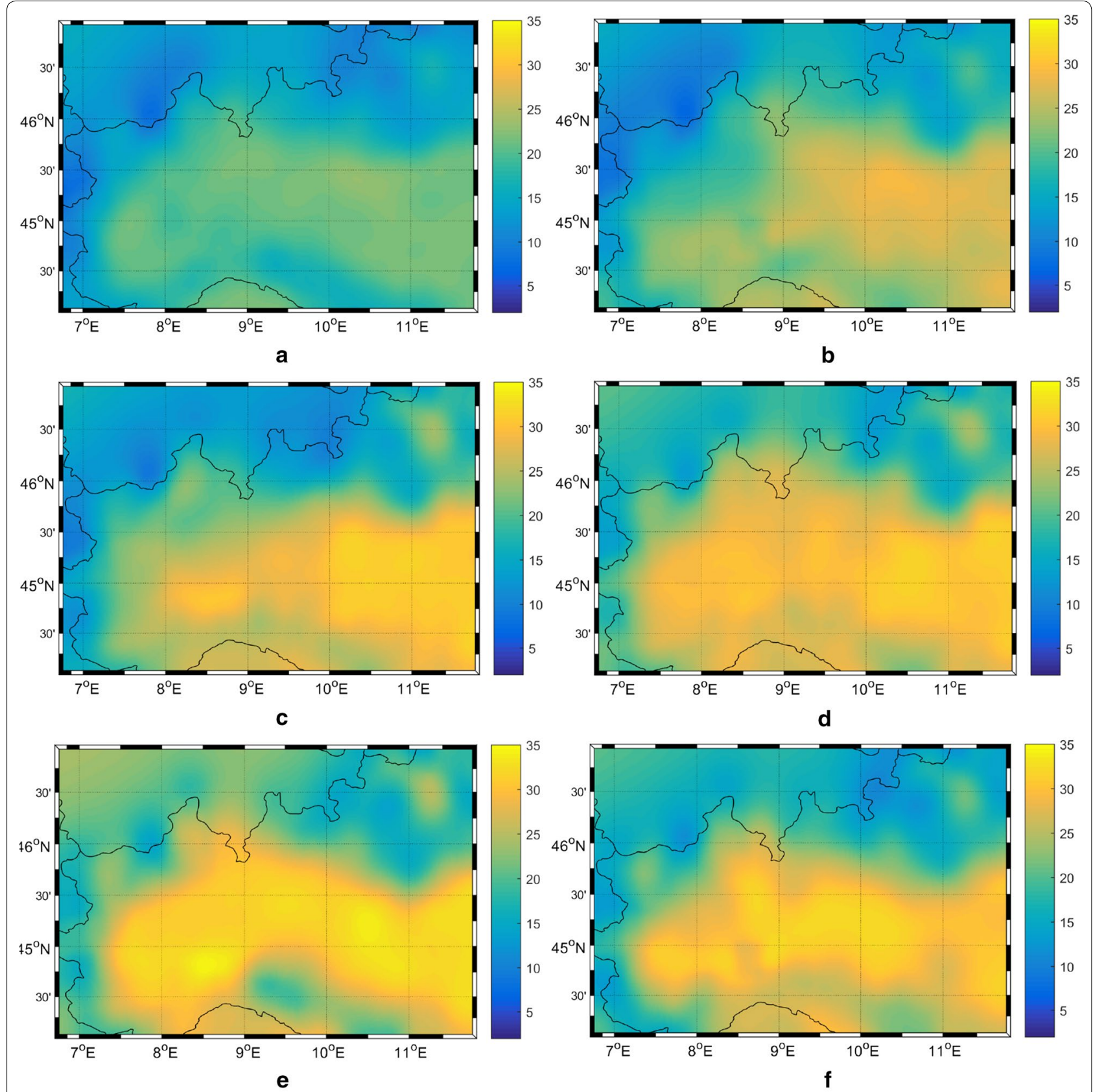

Fig. 5 Time progression of the July 22, 2016, event (a, $\mathbf{c}, \mathbf{e})$ and the July 26, 2016, event ( $\mathbf{b}, \mathbf{d}, \mathbf{f})$, as seen through temperature maps derived from weather stations observations. Temperature values in degrees Celsius. LT local time. a July 22-07:00 LT. b July 26—12:00 LT. c July 22—10:00 LT. d July 26-15:00 LT. e July 22-13:00 LT. f July 26-18:00 LT

series, zenith hydrostatic delays (ZHD) were computed (Saastamoinen 1973) and subtracted from the estimated ZTD to obtain ZWD time series. The ZWD time series were then transformed into the final PWV 30-s time series following Askne and Nordius (1987). PWV values from ZTD are named PWV goGPS and PWV $\mathrm{PoGPS}_{\text {go }}$ if derived from equally weighted or elevation weighted observation adjustments, respectively.

\section{Case studies}

Two different intense rain events that occurred on July 22 and July 26, 2016, over northern Italy were considered. A qualitative description of the rain events is provided by maps of rain intensity derived from radar reflectivity observations (Fig. 4). Figure 5 shows the corresponding maps of observed temperature, interpolated from the weather station data by kriging. The July 22, 2016, event 


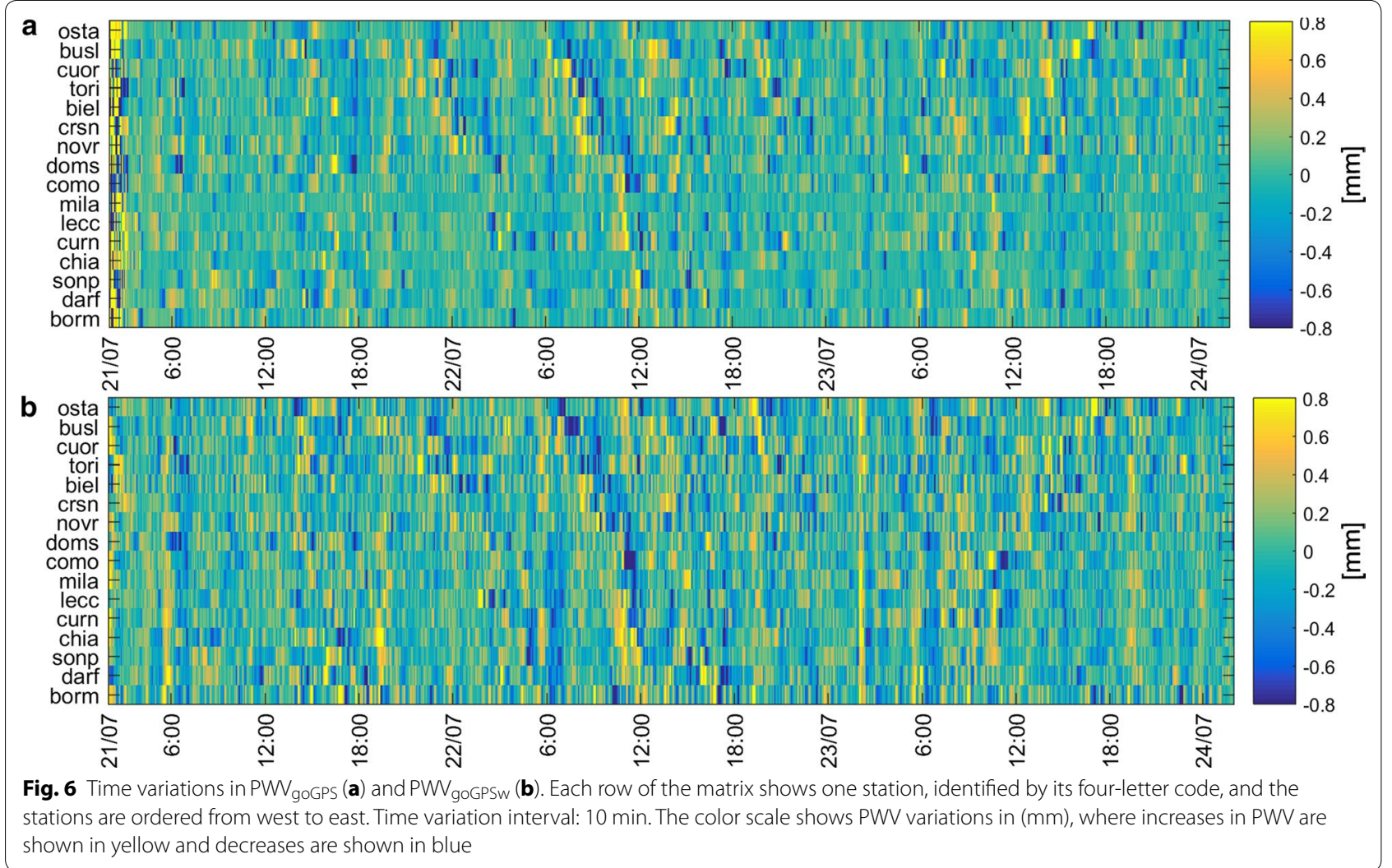

was characterized by a widespread intense rain front that moved from southwest to northeast, passing through the Piedmont and Lombardy regions over about $8 \mathrm{~h}$, from 06:00 to 14:00 local time (LT). In contrast, the July 26 , 2016, rain event was characterized by sparse precipitation cells that developed over these regions in a continuous process of generation and dissipation that also lasted for about $8 \mathrm{~h}$, from 12:00 to 20:00 LT. For this second event, attention was focused on the convective cell reaching cloudburst level at around 18:00 LT with both heavy rain and hail. This cell is visible at the center of the radar image in Fig. 4f, represented with a color corresponding to $110-440 \mathrm{~mm} / \mathrm{h}$ range.

\section{Results and discussion \\ Validation of goGPS PWV against radiosonde and Bernese PWV}

Italian radiosonde stations are managed by the Italian Air Force, which makes the observations available to the European Centre for Medium-Range Weather Forecasts (ECMWF). The University of Wyoming Web site provides a convenient way to access and download global radiosonde data (Oolman 2017). For each radiosonde launch, the integral PWV values are computed and are published together with the sensed values along the vertical profile above the radiosonde station. PWV values from the radiosonde stations of Milano Linate and Cuneo Levaldigi were compared with PWV values derived from the two GNSS stations of MILA and SAVI, respectively, from July 16 to July 31, 2016. Two radiosonde launches per day over 16 days resulted in $32 \mathrm{PWV}$ data points. The height difference between the GNSS and radiosonde stations is limited to $10 \mathrm{~m}$ for the first case study and is $53 \mathrm{~m}$ for the second case study. These differences were accounted for by using the Saastamoinen model for wet delays (Saastamoinen 1973). The statistics of the differences between the PWV values from the radiosonde stations and those derived from GNSS are reported in Table 1. For both radiosonde sites, the PWV $\mathrm{V}_{\text {goGPS }}$ estimates show a bias of less than $1 \mathrm{~mm}$ with respect to $P W V_{\text {radiosonde, with a }}$ standard deviation of less than $2 \mathrm{~mm}$, in agreement with other comparisons between GNSS and radiosondes available in the literature (Van Baelen et al. 2005; Fujita et al. 2008; Sato et al. 2013; Realini et al. 2014).

However, the values of PWV derived from PWV $\mathrm{PoGPSw}_{\mathrm{g}}$ exhibit a wet bias about $0.5 \mathrm{~mm}$ larger than PWV $\mathrm{PoGPS}_{\text {go }}$ while the standard deviation is very similar. This could be due to the worse parameter estimates in the GNSS weighted adjustment, as reported in (Rothacher and Beutler 1998). This bias does not affect the results 

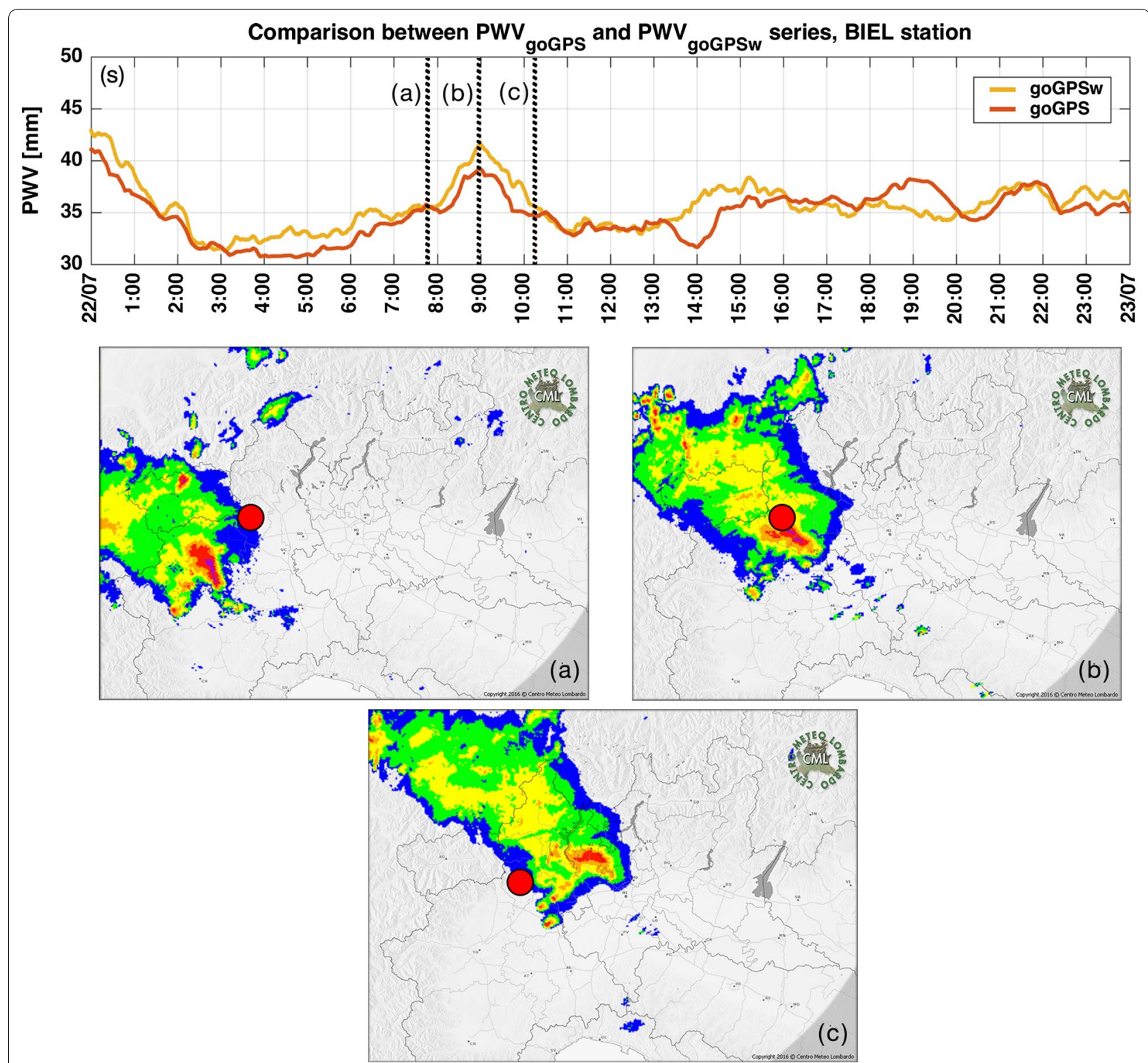

Fig. 7 In the subfigure(s), the BIEL station PWV goGPs and PWV goGPSw time series. On the bottom, radar images corresponding to a the epoch when the precipitation starts passing over the station, $\mathbf{b}$ to the epoch when it completely surrounds the station, and $\mathbf{c}$ to the epoch when it starts leaving the station

Table 1 Statistics of the differences between the goGPS-derived and radiosonde-derived PWV values

\begin{tabular}{|c|c|c|c|c|c|}
\hline \multirow[t]{2}{*}{ Stations } & \multirow[t]{2}{*}{ Distance (km) } & \multicolumn{2}{|c|}{ PWV $_{\text {goGPS }}-$ PWV $_{\text {radiosonde }}$} & \multicolumn{2}{|c|}{$\mathrm{PWV}_{\text {goGPSw }}-\mathrm{PWV}_{\text {radiosonde }}$} \\
\hline & & Mean (mm) & Std $(\mathrm{mm})$ & Mean (mm) & Std (mm) \\
\hline SAVI-16113 & 10.9 & 0.47 & 1.47 & 0.90 & 1.55 \\
\hline MILA-16080 & 6.6 & 0.91 & 1.73 & 1.67 & 1.84 \\
\hline
\end{tabular}


Table 2 Mean and standard deviation of the difference between goGPS-estimated PWV and the Bernese-estimated PWV for each station

\begin{tabular}{|c|c|c|c|c|}
\hline \multirow[t]{2}{*}{ Station } & \multicolumn{2}{|c|}{$\mathrm{PWV}_{\text {goGPS }}-\mathrm{PWV}_{\text {Bernese }}$} & \multicolumn{2}{|c|}{ PWV $_{\text {goGPSw }}-$ PWV $_{\text {Bernese }}$} \\
\hline & Mean (mm) & Std $(\mathrm{mm})$ & Mean $(\mathrm{mm})$ & Std $(\mathrm{mm})$ \\
\hline BIEL & 0.2 & 2.5 & 1.0 & 2.2 \\
\hline BORM & -0.2 & 2.3 & 1.5 & 2.0 \\
\hline BRES & 0.2 & 1.9 & 1.2 & 1.7 \\
\hline BUSL & 0.3 & 2.8 & 1.7 & 2.1 \\
\hline CANL & -0.1 & 2.2 & 0.9 & 1.6 \\
\hline $\mathrm{CHIA}$ & 2.2 & 2.3 & 2.4 & 2.1 \\
\hline сOMO & 0.2 & 1.8 & 1.1 & 2.0 \\
\hline CREA & 0.0 & 2.3 & 0.9 & 1.9 \\
\hline CREM & 0.1 & 2.6 & 0.9 & 1.8 \\
\hline CRSN & 0.1 & 2.3 & 0.6 & 1.9 \\
\hline CUOR & -0.3 & 2.6 & 0.5 & 2.1 \\
\hline CURN & 0.2 & 2.2 & 1.2 & 1.8 \\
\hline DARF & 0.4 & 2.4 & 1.4 & 2.3 \\
\hline DOMS & 0.7 & 2.7 & 1.7 & 2.2 \\
\hline LECC & 0.5 & 2.3 & 1.4 & 2.0 \\
\hline MANT & 0.4 & 1.8 & 1.2 & 1.6 \\
\hline MILA & 0.0 & 2.4 & 0.9 & 1.7 \\
\hline MONV & -0.1 & 2.3 & 0.4 & 2.0 \\
\hline NOVR & -0.2 & 1.9 & 0.9 & 1.8 \\
\hline OSTA & 0.3 & 2.9 & 1.4 & 2.3 \\
\hline PAVI & -0.3 & 2.1 & 0.9 & 1.7 \\
\hline SAVI & 0.1 & 2.1 & 0.8 & 1.6 \\
\hline SONP & 0.4 & 2.4 & 1.5 & 1.8 \\
\hline TORI & 0.4 & 2.4 & 1.0 & 2.0 \\
\hline VARZ & 0.4 & 1.8 & 1.1 & 1.6 \\
\hline
\end{tabular}

presented here, which are based on the variations in ZTD values between different epochs.

Bernese was run on a subset of the dataset (July 21-23, 2016). The comparison between PWV $V_{\text {goGPS }}$ and PWV $\mathrm{P}_{\text {Bernese }}$ shows a very small bias and a standard deviation of about $2 \mathrm{~mm}$ (Table 2). The application of elevation-dependent weighting also introduces a bias for $\mathrm{PWV}_{\text {goGPSw }}$ in this case, with a magnitude ranging from 0.4 to $2.4 \mathrm{~mm}$.

\section{PWV time variation analysis}

Figure 6 reports the time variation of the PWV $\mathrm{goGPS}_{\text {and }}$ PWV $_{\text {goGPSw }}$ time series estimated for the SPIN network stations falling within the July 22, 2016, storm area. A time interval of $10 \mathrm{~min}$ was chosen to enhance detection of the decrease in PWV following the rain event. This decrease lasts for about an hour. If the time interval were shorter, higher frequency variations, which are most likely due to spurious fluctuations, would also be captured. In Fig. 6, each row of the matrix is related to one station, and the stations are ordered from west to east in order to highlight PWV time variations associated with the passage of the storm front. The storm front passed over the region of interest from about 6:00 to 14:00 LT. Figure 6 shows a sequence of rapid PWV decrements for each station (blue color in Fig. 6), starting from OSTA at 6:00 LT and reaching SONP just after 12:00 LT. This behavior is more clearly visible in the case of PWV $\mathrm{goGPS}_{\text {; }}$ this is likely due to the PWV $V_{\text {goGPS }}$ time series being smoothed by averaging among all the satellite-receiver slant delays, which are equally weighted. The satellite elevation-dependent weighting used to obtain PWV $V_{\text {goGPSw}}$, instead weights the slant delays closer to the zenith direction more heavily, increasing the temporal resolving capability of the GNSS estimation algorithm, and thus enhancing its ability to detect PWV fluctuations. The behavior of the PWV variations for the two easternmost stations, DARF and BORM, appears to be uncorrelated with the other stations.

To obtain a clearer understanding of the PWV behavior as the storm front passes, the PWV time series of BIEL, BUSL, COMO, and NOVR stations for the July 22, 2016, event are shown in Figs. 7, 8, 9, and 10, along with the three radar images of precipitation intensity corresponding to the epoch at which the rain event starts passing over the stations [labeled with (a)], the epoch when the rain event is completely surrounding the stations [labeled with (b)], and the epoch when the rain event has passed the stations [labeled with (c)]. The comparison between PWV time series and radar images highlights that the passage of the rain front leads to a peak in PWV as the heavier precipitation radar echoes surround the examined stations. Subsequently, a steep decrease of 5-10 $\mathrm{mm}$ over about an hour is evident. This decrease ends after the front has moved out of range. The PWV behavior preceding the rain event varies from station to station and does not display a clearly identifiable pattern, other than a general increasing trend in the PWV values. This increase could be caused by the fact that by its nature, ZWD (and thus PWV as well) weights the delays of all the satellites in view without considering the anisotropy generated by the arrival direction of the rain front; depending on whether satellites are actually available in that direction, and on the number of available satellites, the PWV increment before the rain event could be more (or less) strongly emphasized. The PWV time variations associated with widespread meteorological events are effectively detected by a network of GNSS receivers deployed at the regional scale, i.e., with inter-station distances on the order of tens of kilometers. We note that the present study does not state that the analysis of GNSS-derived PWV time series alone is sufficient to detect rain events; a steep decrease in these values can occur in the absence of a rain event. Rather, our analysis shows that when a rain event does occur, it affects the PWV values. 

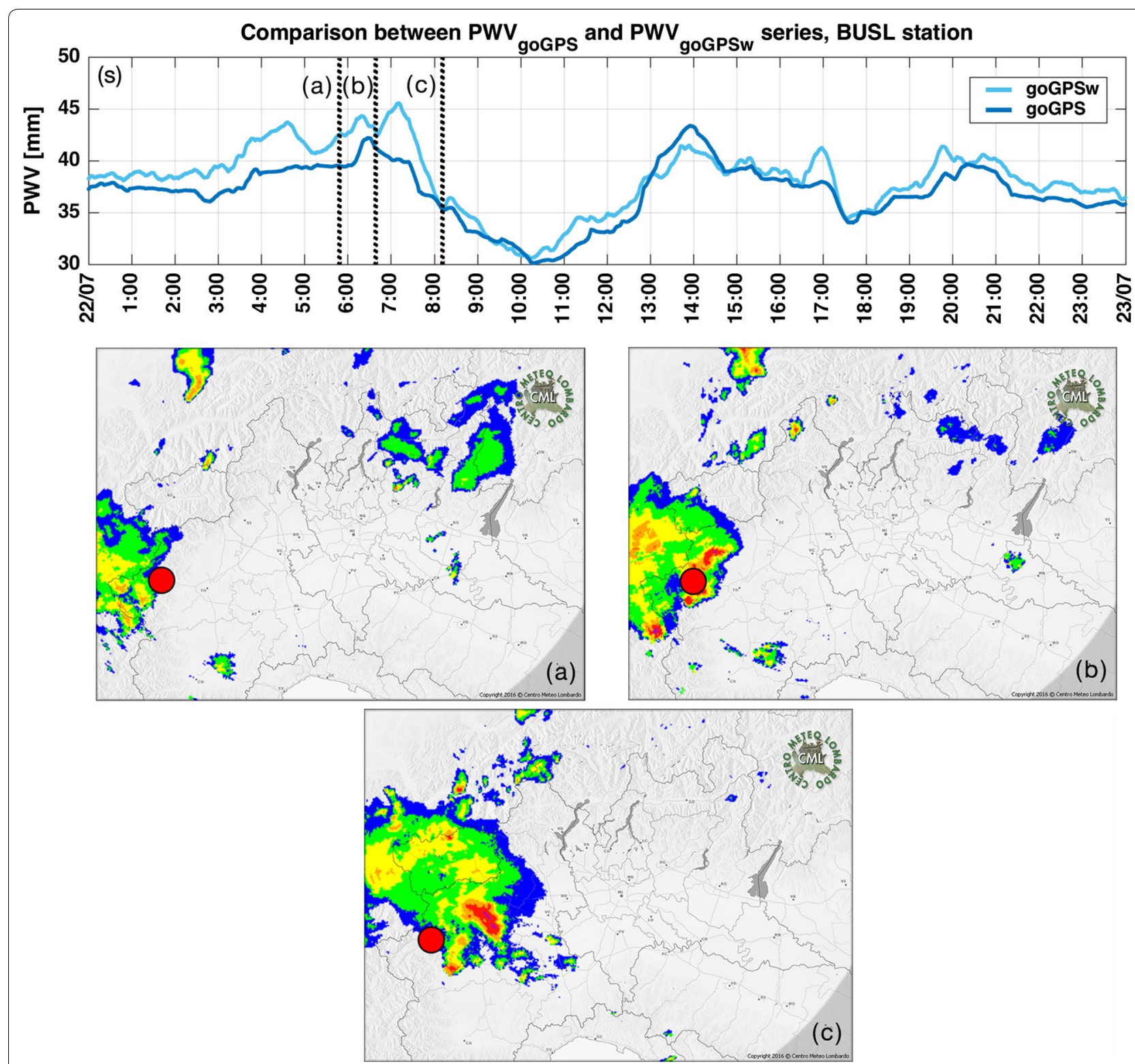

Fig. 8 In the subfigure(s), the BUSL station PWV goGPs and PWV goGPSw time series. On the bottom, the three radar images corresponding to a the epoch when the precipitation starts passing over the station, $\mathbf{b}$ to the epoch when it completely surrounds the station, and $\mathbf{c}$ to the epoch when it starts leaving the station

Based on the results obtained in the first case study, the second event on July 26, 2016, was analyzed by means of $\mathrm{PWV}_{\text {goGPSw }}$ time series alone, since they were found to be better at detecting PWV time variations. Furthermore, the 1-mm wet bias does not affect the characterization of local water vapor fluctuations associated with the localized convective phenomenon which is the object of this study. Figure 11 shows the PWV goGPSw time series for the three geodetic stations in the vicinity of the convective precipitation, the time evolution of which is reported in the radar images in the same figure. MILA and COMO, the closest stations belonging to the SPIN regional network, are too far apart to effectively monitor the PWV variations associated with the local heavy rain event, and thus, their time series do not show significant fluctuations during the time of interest (from 15:00 to 16:00 LT). However, CATU station (belonging to NetGeo network), although being only partially affected by the convective rainfall, captures a strong fluctuation of PWV during the time of interest. Contrary to the July 22, 2016, event, the PWV experiences first a steep decrease, followed by a similarly steep increase. This shows clearly that, without the presence of CATU station, the SPIN receivers would not have been able to observe the convective rain cell that was the object of the study. 


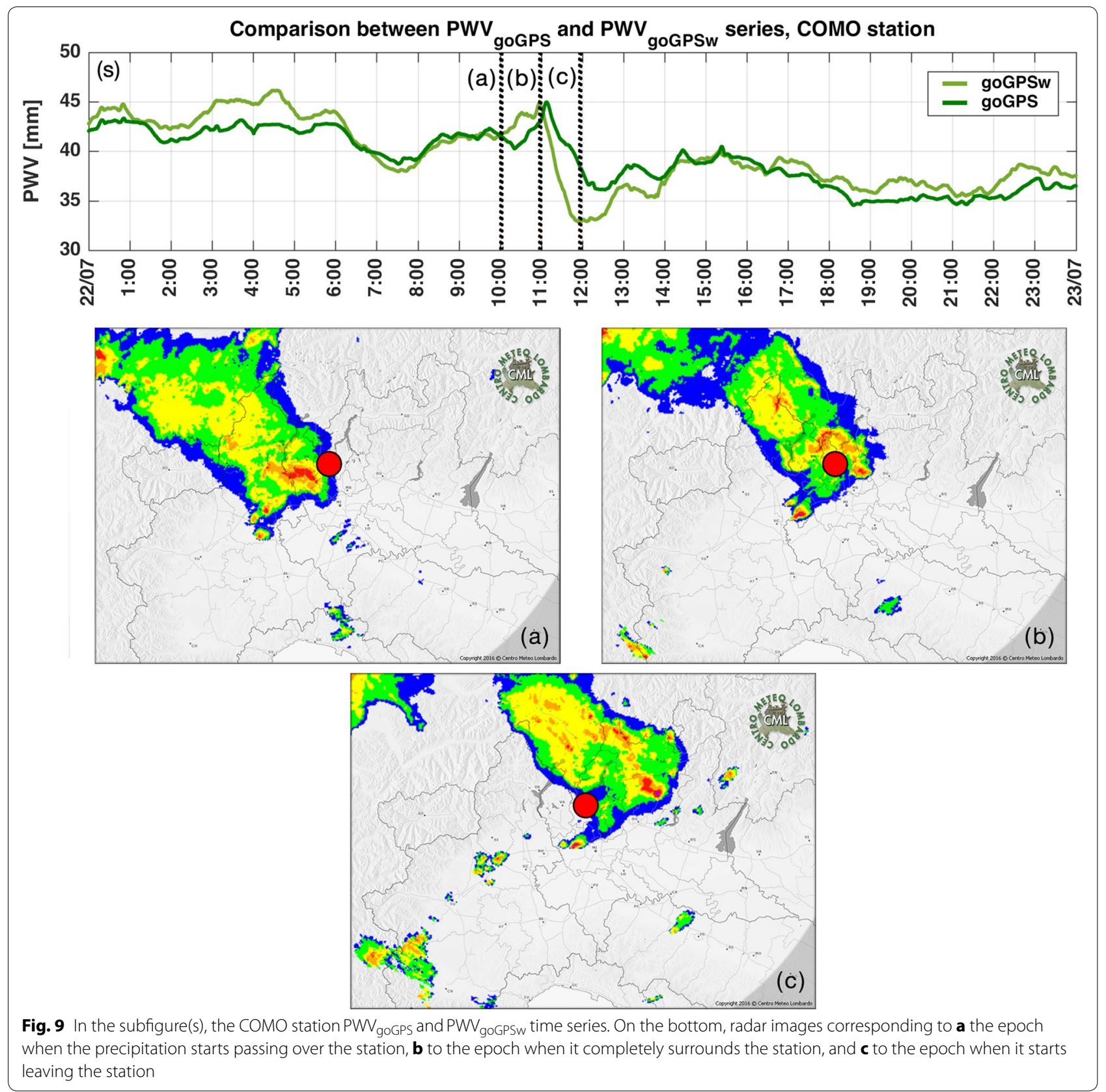

The PWV time series of the low-cost GRED receiver, the only GNSS station available within the July 26, 2016, rainfall area, was compared to the PWV series of CATU station (Fig. 12). It is worth noting that, in this case, it was necessary to perform the preliminary step of ionospheric delay interpolation from the surrounding three stations of COMO, NOVR, and MIL to compensate for the lack of a second frequency for the low-cost L1-only receiver. Figure 12 shows that CATU and GRED stations, which are separated by about $8 \mathrm{~km}$, show similar behavior, especially before the convective rain event.
However, further analyses are required to understand the abnormal increasing trend in the PWV values of GRED station beginning around 17:00 LT. This steep increase corresponds to the time period where a decrease in PWV would have been expected, due to the extinction of the convective storm. Further developments of the goGPS algorithms used to process data from low-cost receivers are planned to avoid abnormal behaviors such as that shown in Fig. 12. A further experimental activity was performed comparing a low-cost receiver to a geodetic station. By applying the SEID approach to deal with the 

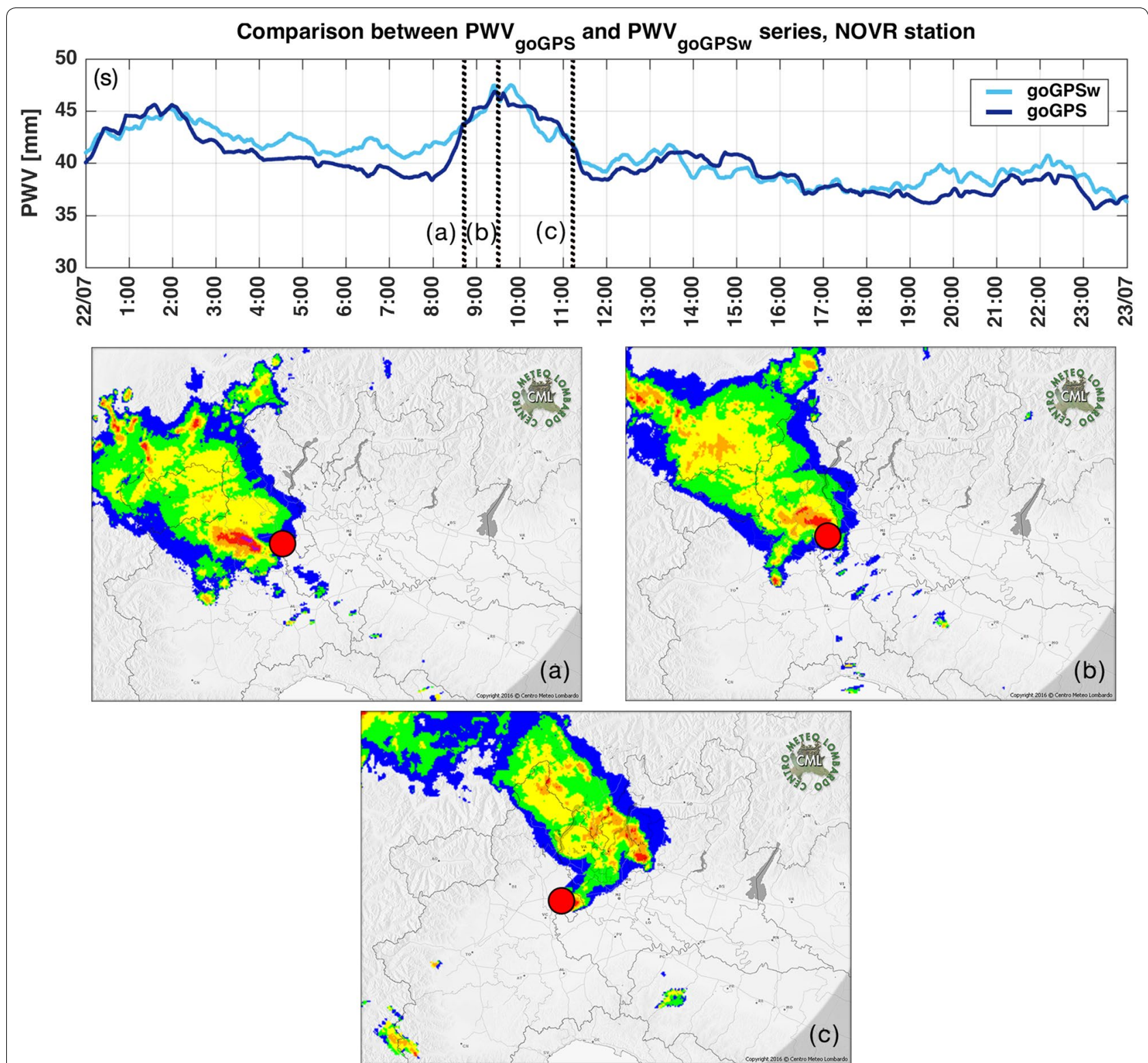

Fig. 10 In the subfigure(s), the NOVR station PWV goGPs and PWV goGPSw time series. On the bottom, radar images corresponding to a the epoch when the precipitation starts passing over the station, $\mathbf{b}$ to the epoch when it completely surrounds the station, and $\mathbf{c}$ to the epoch when it starts leaving the station

ionospheric delay in both cases, the PWV values derived from the analysis of the low-cost receiver were compared to those obtained from the analysis of a co-located geodetic dual-frequency receiver that mimics an L1-only station. This comparison was made using the data from a period of 20 days in April 2017, a different time period from that considered in the rest of the paper, as the geodetic station was not available in July 2016. We first validate the PWV values obtained from the analysis of the
L1-only data from the geodetic station against the PWV values obtained from an iono-free combination to assess the error due to the SEID approach. This error amounts to $0.4 \mathrm{~mm} \pm 0.3 \mathrm{~mm}$ for the entire period. Then, we compare the PWV values of the geodetic (L1-only) and lowcost stations, obtaining an average difference of $0.5 \mathrm{~mm}$ with a standard deviation of $0.4 \mathrm{~mm}$ for the entire time period under study. A representative 1-week subset of the compared time series is shown in Fig. 13. 

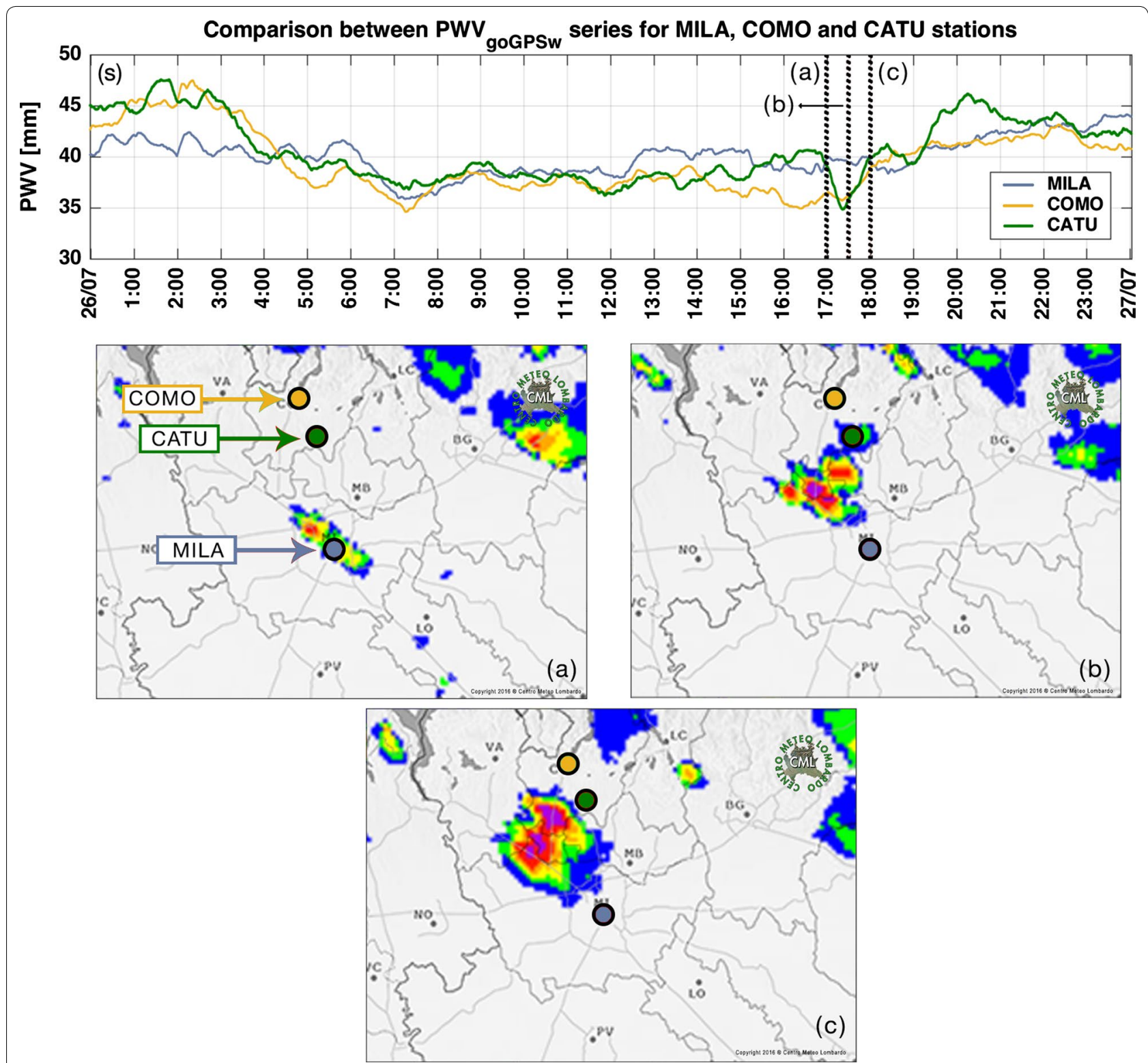

Fig. 11 July 26, 2016, event PWV goGPSw values of the stations affected by the rain event: MILA, CATU, and COMO

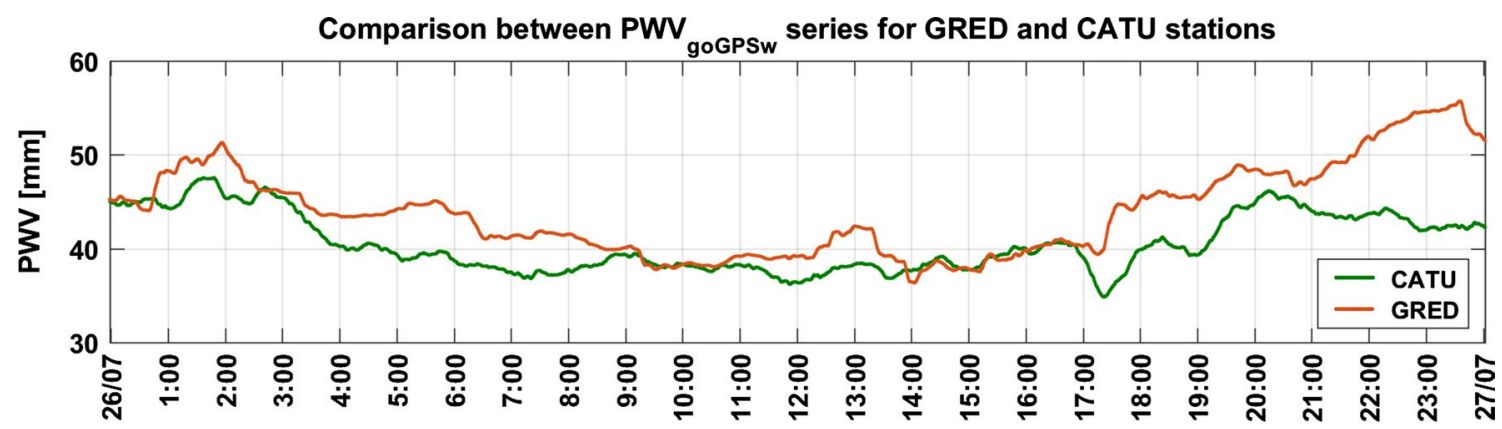

Fig. 12 July 26, 2016, event PWV goGPSw values for CATU and GRED stations 


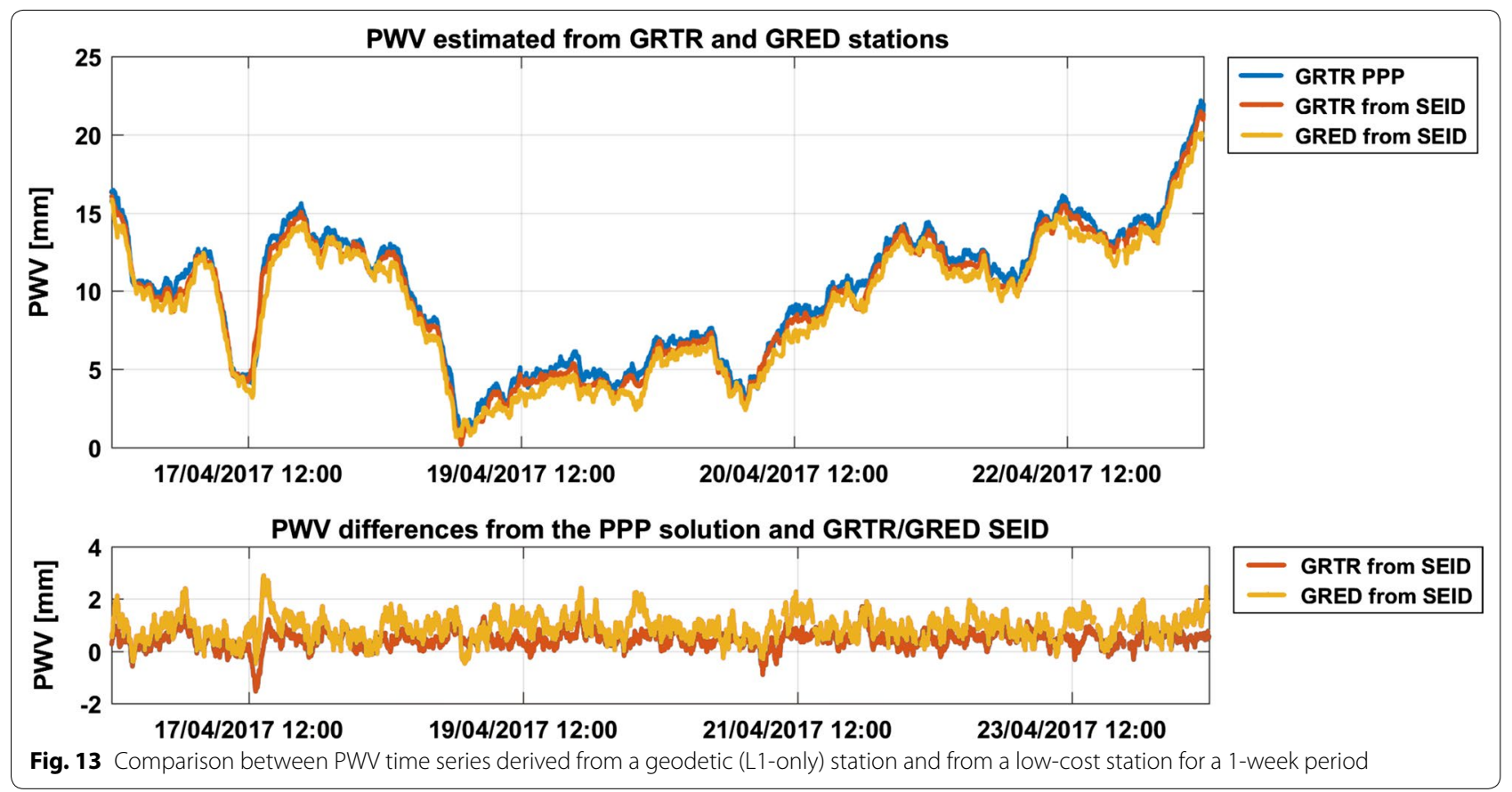

\section{Conclusions}

The objective of this work was to evaluate to what extent PWV time variations associated with heavy rain events could be successfully captured by existing regional GNSS networks in northern Italy. Two intense precipitation events were studied: one characterized by a large rain front moving from west to east, involving the northern half of both Piedmont and Lombardy regions, and a second one characterized by sparse convective cells a few kilometers in extent. A clear pattern was found in the analyzed PWV time series corresponding to the first rain event studied: the PWV decreased steeply by about 5-10 $\mathrm{mm}$ after the passage of the rain front for all the stations within the rainfall area. The analysis of the second rain event clearly demonstrates the need for higher spatial resolution water vapor measurements. Dense networks of GNSS receivers could provide the required observations. This was experimentally verified by comparing the PWV derived from 3 geodetic GNSS receivers. This comparison showed that convective, localized rain phenomena do not affect PWV time series derived from GNSS receivers which, even if close to the phenomenon, are not directly impacted by it. As a last step, in the framework of the second rain event experiment, the PWV values obtained from a single-frequency GNSS receiver were compared to those of a nearby geodetic station. Both stations were directly impacted by one of the localized rain cells. The overall behavior of the low-cost PWV time series agrees with one of the geodetic stations for the period affected by the heavy rain; after this event, the two series display significantly different trends, which need to be better investigated. Although low-cost single-frequency receivers are a promising solution to the problem of densifying GNSS networks, they still present some technological limitations and require further development and calibration.

\section{Abbreviations}

GNSS: global navigation satellite systems; LT: local time; LSC: least-squares collocation; PPP: precise point positioning; PWV: precipitable water vapor; WMO: world meteorological organization; ZHD: zenith hydrostatic delay; ZTD: zenith total delay; ZWD: zenith wet delay.

\section{Authors' contributions}

SB and ER designed the study, developed the methodology, and collected the data; $\mathrm{SB}, \mathrm{ER}, \mathrm{GV}, \mathrm{AF}$, and $\mathrm{AG}$ performed the analysis; $\mathrm{SB}, \mathrm{ER}$, and $\mathrm{GV}$ wrote the

manuscript. All authors read and approved the final manuscript.

\section{Authors' information}

SB, Msc in Environmental Engineering, is a Ph.D. candidate in Geodesy and Geomatics at Politecnico di Milano. ER, Ph.D. in Geodesy and Geomatics, is working for the R\&D company GReD, spin-off of Politecnico di Milano. GV, Ph.D. is Associate Professor in Geodesy and Geomatics at Politecnico di Milano AF, Ph.D. in mathematics, is a temporary research fellow and a Ph.D. candidate in Geodesy and Geomatics at Politecnico di Milano. AG, Ph.D. in Geodesy and Geomatics is a temporary research fellow at Politecnico di Milano.

\section{Author details}

${ }^{1}$ Department of Civil and Environmental Engineering, Politecnico di Milano, Piazza Leonardo da Vinci 32, 20133 Milan, Italy. ${ }^{2}$ Geomatics Research and Development (GReD) srl, via Cavour 2, 22074 Lomazzo, Como, Italy.

\section{Acknowlegements}

The authors acknowledge ARPA Lombardia and ARPA Piemonte, who kindly provided the weather stations data. The authors acknowledge as well Centro Meteorologico Lombardo for the precipitation intensity maps, based on MeteoSwiss radar data, and Dr. Daniele Sampietro for the interpolated temperature maps.

\section{Competing interests}

The authors declare that they have no competing interests. 
Appendix: Hardware setup

Details concerning the hardware setup are reported in

Tables 3, 4, and 5 .

Table 3 Details for the Lombardy weather station network

\begin{tabular}{|c|c|c|c|c|c|c|c|}
\hline \multicolumn{8}{|c|}{ Lombardy } \\
\hline \multirow[t]{2}{*}{ ID } & \multirow[t]{2}{*}{ Town } & \multirow[t]{2}{*}{ Latitude $\left({ }^{\circ}\right)$} & \multirow[t]{2}{*}{ Longitude $\left(^{\circ}\right)$} & \multirow[t]{2}{*}{ Height (mm) } & \multicolumn{3}{|c|}{ Sensors type } \\
\hline & & & & & Pressure & Temperature & Precipitation \\
\hline 1 & Campodolcino & 46.42 & 9.37 & 1880 & Yes & Yes & Yes \\
\hline 2 & Motta Visc. & 45.28 & 8.99 & 100 & No & Yes & Yes \\
\hline 3 & Darfo B.T. & 45.87 & 10.18 & 222 & Yes & Yes & Yes \\
\hline 4 & Laveno-Mom. & 45.91 & 8.65 & 951 & Yes & Yes & Yes \\
\hline 5 & Canevino & 44.93 & 9.28 & 455 & Yes & Yes & Yes \\
\hline 6 & Milano & 45.47 & 9.22 & 122 & Yes & Yes & Yes \\
\hline 7 & Lonate Pozz. & 45.59 & 8.74 & 204 & Yes & Yes & Yes \\
\hline 8 & Crema & 45.37 & 9.70 & 79 & Yes & Yes & Yes \\
\hline 9 & Pavia & 45.19 & 9.16 & 77 & Yes & Yes & Yes \\
\hline 10 & Como & 45.82 & 9.07 & 201 & Yes & Yes & Yes \\
\hline 11 & Mantova & 45.16 & 10.80 & 22 & Yes & Yes & Yes \\
\hline 12 & Cremona & 45.14 & 10.04 & 43 & Yes & Yes & Yes \\
\hline 13 & Sondrio & 46.17 & 9.88 & 290 & Yes & Yes & Yes \\
\hline 14 & Bergamo & 45.70 & 9.67 & 249 & No & yes & Yes \\
\hline 15 & Brescia & 45.51 & 10.22 & 125 & Yes & Yes & Yes \\
\hline 16 & Valdisotto & 46.46 & 10.34 & 2295 & Yes & Yes & Yes \\
\hline 17 & Molteno & 45.78 & 9.31 & 278 & Yes & Yes & Yes \\
\hline
\end{tabular}

Table 4 Details for the Piedmont weather station network

\begin{tabular}{|c|c|c|c|c|c|c|c|}
\hline \multicolumn{8}{|c|}{ Piedmont } \\
\hline \multirow[t]{2}{*}{ ID } & \multirow[t]{2}{*}{ Town } & \multirow[t]{2}{*}{ Latitude $\left({ }^{\circ}\right)$} & \multirow[t]{2}{*}{ Longitude $\left({ }^{\circ}\right)$} & \multirow[t]{2}{*}{ Height (m) } & \multicolumn{3}{|c|}{ Sensors type } \\
\hline & & & & & Pressure & Temperature & Precipitation \\
\hline 1 & Alessandria & 44.94 & 8.70 & 90 & Yes & Yes & Yes \\
\hline 2 & Biella & 45.56 & 8.06 & 405 & No & Yes & Yes \\
\hline 3 & Demonte & 44.32 & 7.31 & 765 & No & Yes & Yes \\
\hline 4 & Domodossola & 46.10 & 8.30 & 252 & No & Yes & Yes \\
\hline 5 & Gavi & 44.69 & 8.80 & 215 & No & Yes & Yes \\
\hline 6 & Marene & 44.67 & 7.73 & 310 & No & Yes & Yes \\
\hline 7 & Mondovì & 44.40 & 7.81 & 422 & No & Yes & Yes \\
\hline 8 & Nizza Monferrato & 44.76 & 8.35 & 138 & No & Yes & Yes \\
\hline 9 & Novara & 45.44 & 8.63 & 151 & Yes & Yes & Yes \\
\hline 10 & Paesana Erasca & 44.68 & 7.26 & 638 & No & Yes & Yes \\
\hline 11 & Paruzzaro & 45.75 & 8.51 & 332 & No & Yes & Yes \\
\hline 12 & Susa & 45.14 & 7.05 & 520 & No & Yes & Yes \\
\hline 13 & Sparone & 45.41 & 7.54 & 550 & No & Yes & Yes \\
\hline 14 & Torino & 45.08 & 7.68 & 290 & No & Yes & Yes \\
\hline 15 & Verolengo & 45.19 & 8.01 & 163 & No & Yes & Yes \\
\hline 16 & Bra & 44.70 & 7.85 & 298 & Yes & No & No \\
\hline 17 & Torino & 45.19 & 7.65 & 300 & Yes & No & No \\
\hline 18 & Macugnaga & 45.95 & 7.92 & 2075 & Yes & No & No \\
\hline
\end{tabular}


Table 5 Details for the GNSS network

\begin{tabular}{|c|c|c|c|c|c|c|c|}
\hline Label & Town & Latitude $\left({ }^{\circ}\right)$ & Longitude $\left({ }^{\circ}\right)$ & Height (m) & Network & Receiver & Antenna \\
\hline ASLN & Alessandria & 44.92 & 8.62 & 147 & SPIN & LEICA GRX1200 & LEIAR25.R3 LEIT \\
\hline BIEL & Biella & 45.56 & 8.05 & 480 & SPIN & LEICA GRX1200 & LEIAR25.R3 LEIT \\
\hline BORM & Bormio & 46.47 & 10.36 & 1.263 & SPIN & TPS NETG3 & TPSCR3_GGD CONE \\
\hline BRES & Brescia & 45.56 & 10.23 & 225 & SPIN & TPS NETG3 & TPSCR3_GGD CONE \\
\hline BUSL & Bussoleno & 45.14 & 7.15 & 496 & SPIN & LEICA GRX1200 & LEIAR25.R3 LEIT \\
\hline CANL & Canelli & 44.72 & 8.29 & 206 & SPIN & LEICA GRX1200 & LEIAR25.R3 LEIT \\
\hline $\mathrm{CHIA}$ & Chiavenna & 46.32 & 9.40 & 392 & SPIN & TPS NETG3 & TPSCR3_GGD CONE \\
\hline COMO & Como & 45.80 & 9.10 & 292 & SPIN & TPS NET-G5 & TPSCR.G3 TPSH \\
\hline CREA & Crema & 45.35 & 9.69 & 130 & SPIN & TPS ODYSSEY_E & TPSCR3_GGD CONE \\
\hline CREM & Cremona & 45.15 & 10.00 & 103 & SPIN & TPS ODYSSEY_E & TPSCR3_GGD CONE \\
\hline CRSN & Crescentino & 45.19 & 8.11 & 212 & SPIN & LEICA GRX1200 & LEIAR25.R3 LEIT \\
\hline CUOR & Cuorgnè & 45.39 & 7.65 & 483 & SPIN & LEICA GRX1200 & LEIAR25.R3 LEIT \\
\hline CURN & Curno & 45.69 & 9.61 & 298 & SPIN & TPS NETG3 & TPSCR3_GGD CONE \\
\hline DARF & Darfo B.T. & 45.88 & 10.18 & 283 & SPIN & TPS ODYSSEY_E & TPSCR.G3 TPSH \\
\hline DEMN & Demonte & 44.32 & 7.29 & 863 & SPIN & LEICA GRX1200+GNSS & LEIAR25.R3 LEIT \\
\hline DOMS & Domodossola & 46.12 & 8.29 & 366 & SPIN & LEICA GRX1200+GNSS & LEIAR25.R3 LEIT \\
\hline GOZZ & Gozzano & 45.75 & 8.43 & 417 & SPIN & LEICA GRX1200+GNSS & LEIAR25.R3 LEIT \\
\hline LECC & Lecco & 45.85 & 9.40 & 274 & SPIN & TPS ODYSSEY_E & TPSCR3_GGD CONE \\
\hline MANT & Mantova & 45.16 & 10.79 & 79 & SPIN & TPS ODYSSEY_E & TPSCR.G3 TPSH \\
\hline MILA & Milano & 45.48 & 9.23 & 187 & SPIN & TPS NETG3 & TPSCR3_GGD CONE \\
\hline MONV & Mondovì & 44.39 & 7.83 & 638 & SPIN & LEICA GRX1200+GNSS & LEIAR25.R3 LEIT \\
\hline NOVR & Novara & 45.45 & 8.61 & 219 & SPIN & LEICA GRX1200+GNSS & LEIAR25.R3 LEIT \\
\hline OSTA & Ostana & 44.69 & 7.19 & 1309 & SPIN & LEICA GRX1200+GNSS & LEIAR25.R3 LEIT \\
\hline VARZ & Pavia & 45.20 & 9.14 & 144 & SPIN & TPS NET-G5 & TPSCR3_GGD CONE \\
\hline VIGE & Savigliano & 44.65 & 7.66 & 380 & SPIN & LEICA GRX1200+GNSS & LEIAR25.R3 LEIT \\
\hline SERR & Serravalle S. & 44.73 & 8.85 & 251 & SPIN & LEICA GRX1200+GNSS & LEIAR25.R3 LEIT \\
\hline SONP & Sondrio & 46.17 & 9.87 & 372 & SPIN & TPS NETG3 & TPSCR.G3 TPSH \\
\hline TORI & Torino & 45.06 & 7.66 & 311 & SPIN & TPS ODYSSEY_E & LEIAR25.R3 NONE \\
\hline VARZ & Varzi & 44.82 & 9.20 & 469 & SPIN & TPS ODYSSEY_E & TPSCR.G3 TPSH \\
\hline VIGE & Vigevano & 45.31 & 8.86 & 169 & SPIN & TPS ODYSSEY_E & TPSCR3_GGD CONE \\
\hline CATU & Cantù & 45.74 & 9.12 & 364 & NetGEO & TPS NETG3 & TPSG3_A1 \\
\hline GRED & Lomazzo & 45.70 & 9.04 & 322 & GReD & u-blox LEA-6T & Tallysman TW3070 \\
\hline
\end{tabular}

\section{Publisher's Note}

Springer Nature remains neutral with regard to jurisdictional claims in published maps and institutional affiliations.

Received: 31 August 2017 Accepted: 31 January 2018

Published online: 12 February 2018

\section{References}

Askne J, Nordius H (1987) Estimation of tropospheric delay for microwaves from surface weather data. Radio Sci 22(03):379-386

Basili P, Bonafoni S, Ferrara R, Ciotti P, Fionda E, Arnbrosini R (2001) Atmospheric water vapor retrieval by means of both a GPS network and a microwave radiometer during an experimental campaign in Cagliari, Italy, in 1999. IEEE Trans Geosci Remote Sens 39(11):2436-2443

Bennitt GV, Jupp A (2012) Operational assimilation of GPS zenith total delay observations into the Met office numerical weather prediction models. Mon Wea Rev 140(8):2706-2719
Bonafoni S, Biondi R (2016) The usefulness of the global navigation satellite systems (GNSS) in the analysis of precipitation events. Atmos Res 167:15-23

Dach R, Lutz S, Walser P, Fridez P (2015) BERNESE GNSS software version 5.2. University of Bern, Bern Open Publishing

Bevis M, Businger S, Herring TA, Rocken C, Anthes RA, Ware RH (1992) GPS meteorology: remote sensing of atmospheric water vapor using the global positioning system. J Geophys Res Atmos 97(D14):15787-15801

Boccolari M, Fazlagic S, Frontero P, Lombroso L, Pugnaghi S, Santangelo R, Corradini S, Teggi S (2002) GPS Zenith total delays and precipitable water in comparison with special meteorological observations in Verona (Italy) during MAP-SOP. Ann Geophys 45(5):599-608

Böhm J, Niell A, Tregoning P, Schuh H (2006) Global mapping function (GMF) a new empirical mapping function based on numerical weather model data. Geophys Res Lett 33(7):L07304

Caldera S, Realini E, Barzaghi R, Reguzzoni M, Sansò F (2016) Experimental study on low-cost satellite-based geodetic monitoring over short baselines. J Surv Eng 142(3):04015016

Cheng S, Perissin D, Lin H, Chen F (2012) Atmospheric delay analysis from GPS meteorology and InSAR APS. J Atmos Solar Terr Phys 86:71-82 
Ciotti P, Di Giampaolo E, Basili P, Bonafoni S, Mattioli V, Biondi R, Fionda E, Consalvi F, Memmo A, Cimini D, Pacione R (2003) Vespe F (2003) MERIS IPWV validation: a multisensor experimental campaign in the Central Italy. In: MERIS user workshop, ESA/ESRIN, Frascati, Italy

Dach R, Lutz S, Walser P, Fridez P (2015) Bernese GNSS software version 5.2. University of Bern. Bern Open Publishing

De Haan S (2013) Assimilation of GNSS ZTD and radar radial velocity for the benefit of very-short-range regional weather forecasts. Q J R Meteor Soc 139:2097-2107

Deng Z, Bender M, Dick G, Ge M, Wickert J, Ramatschi M, Zou X (2009) Retrieving tropospheric delays from GPS networks densified with single frequency receivers. Geophys Res Lett 36(19):L19802

Faccani C, Ferretti R, Pacione R, Paolucci T, Vespe F, Cucurull L (2005) Impact of a high density GPS network on the operational forecast. Adv Geosci 2:73-79

Ferrando I (2017) GNSS Contribution to Monitor Severe Rainfalls: an Innovative Procedure for Wide and Orographically Complex Area with existing Infrastructures. Dissertation. University of Genoa

Fujita M, Kimura F, Yoneyama K, Yoshizaki M (2008) Verification of precipitable water vapor estimated from shipborne GPS measurements. Geophys Res Lett 35(13):L13803

Guerova G, Jones J, Dousa J, Dick G, de Haan S, Pottiaux E, Bock O, Pacione R, Elgered G, Vedel H, Bender M (2016) Review of the state of the art and future prospects of the ground-based GNSS meteorology in Europe. Atmos Meas Tech 9(11):5385-5406

Herrera AM, Suhandri HF, Realini E, Reguzzoni M, de Lacy MC (2016) goGPS: open-source MATLAB software. GPS Solut 20(3):595-603

Hofmann-Wellenhof B, Lichtenegger H, Collins J (2001) Global positioning system. theory and practice. Springer, Wien

JMA (2013) Outline of the operational numerical weather prediction at the Japan Meteorological Agency. Appendix to WMO technical progress report on the global data-processing and forecasting system (GDPFS) and numerical weather prediction (NWP) research. http://www.jma.go.jp/ jma/jma-eng/jma-center/nwp/outline2013-nwp/index.htm. Accessed 30 Aug 2017

Kouba J, Héroux P (2001) Precise point positioning using IGS orbit and clock products. GPS Solut 5(2):2-28

Notarpietro R, Cucca M, Gabella M, Venuti G, Perona G (2011) Tomographic reconstruction of wet and total refractivity fields from GNSS receiver networks. Adv Space Res 47:898-912
Oolman L (2017) Atmospheric Soundings, University of Wyoming. http:// weather.uwyo.edu/upperair/sounding.html. Accessed 12 Dec 2017

Onn F (2006) Modeling water vapor using GPS with application to mitigating InSAR atmospheric distortions. Dissertation, Stanford University

Pacione R, Pace B , Bianco G. (2013) ASI/CGS products and services in support of GNSS-meteorology. In: EGU general assembly conference abstracts, vol 15

Realini E, Reguzzoni M (2013) goGPS: open source software for enhancing the accuracy of low-cost receivers by single-frequency relative kinematic positioning. Meas Sci Technol 24(11):115010

Realini E, Sato K, Tsuda T, Susilo Manik T (2014) An observation campaign of precipitable water vapor with multiple GPS receivers in western Java, Indonesia. Progress Earth Planet Sci 1(1):17

Rothacher M, Beutler G (1998) The role of GPS in the study of global change. Phys Chem Earth 23(9-10):1029-1040

Saastamoinen J (1973) Contributions to the theory of atmospheric refraction. Bull Géod 107(1):13-34

Saito K, Shoji Y, Origuchi S, Duc L (2017) GPS PWV assimilation with the JMA nonhydrostatic 4DVAR and cloud resolving ensemble forecast for the 2008 August Tokyo metropolitan area local heavy rainfalls. Data assimilation for atmospheric, Oceanic and Hydrologic Applications, vol III, pp 383-404

Sato K, Realini E, Tsuda T, Oigawa M, Iwaki Y, Shoji Y, Seko H (2013) A highresolution, precipitable water vapor monitoring system using a dense network of GNSS receivers. J Dis Res 8(1):37-47

Shoji Y, Nakamura H, Iwabuchi T, Aonashi K, Seko H, Mishima K, Ohtani R (2004) Tsukuba GPS dense net campaign observation: improvement in GPS analysis of slant path delay by stacking one-way postfit phase residuals. J Meteor Soc Jpn 82(1B):301-314

Tammaro U, Riccardi U, Masson F, Capuano P, Boy J P (2016) Atmospheric precipitable water in Somma-Vesuvius area during extreme weather events from ground-based GPS measurements. In: Freymueller JT, Sánchez L (eds) International symposium on earth and environmental sciences for future generations. International Association of Geodesy Symposia, vol 147, Springer, Cham

Teunissen PJG, Kleusberg A (eds) (1998) GPS for geodesy. Springer, Berlin Van Baelen J, Aubagnac J, Dabas A (2005) Comparison of near-real time estimates of integrated water vapor derived with GPS, radiosondes, and microwave radiometer. J Atmos Ocean Tech 22(2):201-210

\section{Submit your manuscript to a SpringerOpen ${ }^{\odot}$ journal and benefit from:}

- Convenient online submission

- Rigorous peer review

- Open access: articles freely available online

- High visibility within the field

- Retaining the copyright to your article

Submit your next manuscript at $\boldsymbol{\nabla}$ springeropen.com 